\title{
ANALÝZA BLACK - SCHOLESOVHO MODELU PRE FUTURES OPCIE
}

\author{
Lucia Vrábelová ${ }^{1}$
}

\section{Úvod}

Už začiatkom dvadsiateho storočia sa začali rozvíjat' obchody s opciami na cenné papiere, ale ich likvidita bola vel'mi nízka, pretože neexistovala možnost' uzavretia pozície alebo nasledovného obchodovania s opciami. K výraznému rozmachu používania finančných derivátov došlo po publikovaní práce, v ktorej bol uvedený Black - Scholesov model oceňovania opcií, ktorý vypracovali F. Black, M. Scholes a R. Merton. Za túto prácu získali M. Scholes a R. Merton v roku 1997 Nobelovu cenu za ekonomiku.

Časový vývoj cien aktív je často nestály a vykazuje rôzne vel'ké fluktuácie, ktoré sú zapríčinené pôsobením burzového a mimoburzového trhu na cenu daného aktíva. Dopyt a ponuka daného aktíva formujú jej časový priebeh. Snahou investorov je minimalizovat' možné straty zapríčinené prudkým poklesom cien aktív. Jedným z efektívnych nástrojov na zabezpečenie sa proti tomuto riziku je použitie zaist’ovacích nástrojov, ktorými sú rôzne druhy derivátov aktív. Podcenenie zaistenia investičného portfólia pomocou derivátov môže spôsobit' vysoké finančné straty.

\section{Základné pojmy}

Finančný derivát je finančný nástroj, ktorého hodnota závisí na hodnote iného finančného aktíva (akcia, burzový index, výmenný kurz).

Opcia je finančný derivát, ktorý dáva jej vlastníkovi právo kúpit’ / predat' dané aktívum (napr. akciu) v danom čase $T$ v budúcnosti za vopred dohodnutú realizačnú cenu $X$. Vyrovnanie opcie nie je povinné, opcia môže vypršat' bez uplatnenia.

Call opcia je kúpna opcia, zaist’uje vlastníkovi právo na kúpu. Put opcia je predajná opcia, dáva vlastníkovi právo predat' aktívum.

ATM opcia (At the money) je opcia, ktorej vnútorná hodnota je v podstate nulová. To je vtedy, ak sa realizačná cena opcie zhoduje (alebo takmer zhoduje) s trhovou cenou podkladového aktíva.

ITM opcia (In the money) je opcia, ktorá má vnútornú hodnotu (je v peniazoch). V prípade kúpnej opcie je to vtedy, ak je cena podkladového aktíva na trhu vyššia ako realizačná cena opcie. V prípade predajnej opcie je to vtedy, ak je cena podkladového aktíva na trhu nižšia ako realizačná cena opcie.

OTM opcia (Out of the money) je opcia bez vnútornej hodnoty. V prípade kúpnej opcie je to vtedy, ak je cena podkladového aktíva na trhu nižšia ako realizačná cena opcie. V prípade predajnej opcie je to vtedy, ak je cena podkladového aktíva na trhu vyššia ako realizačná cena opcie.

\footnotetext{
${ }^{1}$ Mgr. Lucia Vrábelová, Katedra spojov, Fakulta prevádzky a ekonomiky dopravy a spojov, Žilinská univerzita, Univerzitná 1, 01026 Žilina, tel.: 5133140, e-mail: Lucia.Vrabelova@fpedas.utc.sk
} 
Futurita (futures) je dohoda medzi dvoma stranami o kúpe alebo predaji daného aktíva v budúcnosti za vopred dohodnutú cenu. Realizuje sa zvyčajne na burze, ktorá špecifikuje štandartné podmienky tohto obchodu a garantuje účastníkom, že obchod bude realizovaný. Futurity sú štandardizované kontrakty, množstvá, čas, kvalita obchodovatel'ného aktíva, metódy uzatvorenia kontraktu, určenie minimálnej a maximálnej ceny sú stanovené pevne vopred. Obchodovat's nimi sa dá iba v určité dni v roku. Futurity nemajú presne stanovený dátum dodávky podkladového aktíva, určený je len mesiac, $\mathrm{v}$ ktorom sa dodanie musí uskutočnit'. Burza určí, v akom období počas tohto mesiaca sa musí aktívum dodat'. Futures sa od opcií líšia v tom, že ich vyrovnanie je povinné, na rozdiel od opcií, pri ktorých sa môže ich držitel' rozhodnút', či danú opciu uplatní alebo ju nechá vypršat' bez uplatnenia. Vyrovnanie pri futures prebieha každý deň, to znamená, že každý deň sa obchodovanie uzavrie, prebehne vyrovnanie medzi účastníkmi futures kontraktu a ráno sa obchodovanie znovu otvorí pri novej cene.

Futures opcia je špeciálnym typom opcie, ktorej podkladovým aktívom je futures. Pri uplatnení call futures opcie jej vlastník získava dlhú pozíciu vo futures kontrakte (kontrakt na kúpu) plus hotovost', ktorú predstavuje posledná uzatváracia cena futures z predchádzajúceho obchodného dňa. Pri uplatnení put futures opcie jej majitel' získava krátku pozíciu vo futures kontrakte (na predaj aktíva) plus hotovost' vo výške poslednej uzatváracej ceny futures z predchádzajúceho obchodného dňa.

Futures opcie sú pre obchodníkov výhodnejšie ako klasické opcie, pretože majú nižšie transakčné náklady, uplatnenie opcie ešte nevedie priamo k dodávke aktíva a často je jednoduchšie dodat' futures kontrakt ako aktívum.

\section{Black - Scholesov model oceňovania futures opcií}

Black - Scholesov model oceňovania futures opcií vychádza zo zovšeobecneného Black - Scholesovho modelu pre klasické európske opcie, ktoré poskytujú dividendový výnos ${ }^{2}$.

Označíme

$r$ - bezriziková úroková miera,

$q$ - dividendový výnos určený $\mathrm{v} \% \mathrm{z}$ ceny aktíva,

$f$ - cena derivátu,

$t$ - čas do splatnosti derivátu (opcie),

$S$ - cena podkladového aktíva,

$\sigma$ - volatilita ceny akcie.

Black - Scholesova parciálna diferenciálna rovnica má nasledujúci tvar: ${ }^{3}$

$$
r f=\frac{\partial f}{\partial t}+(r-q) S \frac{\partial f}{\partial S}+\frac{1}{2} \sigma^{2} S^{2} \frac{\partial^{2} f}{\partial S^{2}} .
$$

Pri futures opciách v tejto rovnici nahradíme premennú $S$ (cena akcie) cenou futures $F$ a dividendový výnos $q$ nahradíme úrokovou mierou $r$ (pretože musí platit' $q=r$ z dôvodu zabránenia bezrizikovému zisku - arbitráži).

Tým dostávame nasledujúci tvar Black - Scholesovej rovnice pre futures opcie:

$$
r f=\frac{\partial f}{\partial t}+\frac{1}{2} \sigma^{2} F^{2} \frac{\partial^{2} f}{\partial F^{2}}
$$

Stanovením okrajových podmienok a počiatočnej podmienky, ktoré spíňa futures opcia získame riešenie rovnice (2). Toto riešenie je dané: ${ }^{4}$

\footnotetext{
${ }^{2}$ Podrobnejšie je Black - Scholesov model popísaný v [2].

${ }^{3}$ Bližšie odvodenie pozri [2].

${ }^{4}$ Bližšie odvodenie vzorca pozri [2]
} 
kde

$$
c=F e^{-r(T-t)} N\left(d_{1}\right)-X e^{-r(T-t)} N\left(d_{2}\right),
$$

$$
d_{1}=\frac{\ln \frac{F e^{-r(T-t)}}{X}+\left(r+\frac{\sigma^{2}}{2}\right)(T-t)}{\sigma \sqrt{T-t}}=\frac{\ln \frac{F}{X}+\frac{\sigma^{2}}{2}(T-t)}{\sigma \sqrt{T-t}}, \quad d_{2}=d_{1}-\sigma \sqrt{T-t} .
$$

Funkcia $N(x)$ je distribučná funkcia normovaného normálneho rozdelenia.

\section{Analýza Black - Scholesovho modelu oceňovania futures opcií} modelu:

Faktory, ktoré môžu ovplyvnit' cenu futures opcie, sú najmä vstupné parametre tohto

- cena podkladového aktíva $F$ na spotovom trhu,

- realizačná cena $X$,

- doba splatnosti opcie $t$,

- volatilita $\sigma$,

- výška bezrizikovej úrokovej miery $r$,

- výplata dividendy.

Všetky uvedené parametre ovplyvňujú cenu kúpnej i predajnej opcie, ale každý iným spôsobom a v inej miere. Pre obchodníka, ktorý používa finančné deriváty ako spôsob zaistenia sa voči riziku zmien ceny aktív na spotovom trhu, je potrebné zistit', ktorý parameter maximálne ovplyvňuje cenu opcie a nájst' spôsob ako minimalizovat' jeho prípadné nepriaznivé dôsledky na hodnotu portfólia alebo na výsledok investície.

Pre ilustráciu uvedieme analýzu vplyvu zmeny ceny futures na zmenu ceny futures opcie. Cena futures na spotovom trhu je jedným z rozhodujúcich faktorov ovplyvňujúcich cenu kúpnej opcie. Ak predpokladáme, že ostatné vstupné parametre zostanú na konštantnej úrovni, pri zvýšení ceny futures na spotovom trhu pri rovnakej realizačnej cene musí stúpnut' aj cena kúpnej opcie. Teda za rovnakú realizačnú cenu máme právo kúpit' futures s vyššou cenou a musíme za to aj viac zaplatit'. Stúpne aj vnútorná hodnota kúpnej opcie. Investor potrebuje vediet', o akú hodnotu sa zmení cena kúpnej opcie pri určitej zmene ceny futures na spotovom trhu. Táto zmena sa dá vyjadrit’ pomocou parciálnej derivácie funkcie ceny kúpnej futures opcie (3) podl'a parametra $F$.

Po zderivovaní rovnice (3) podl'a $F$ dostávame

$$
\frac{\partial c}{\partial F}=e^{-r(T-t)} N\left(d_{1}\right)+F e^{-r(T-t)} N^{\prime}\left(d_{1}\right) \frac{\partial d_{1}}{\partial F}-X e^{-r(T-t)} N^{\prime}\left(d_{2}\right) \frac{\partial d_{2}}{\partial F},
$$

pričom

$$
\begin{aligned}
& \frac{\partial d_{1}}{\partial F}=\frac{\partial d_{2}}{\partial F}=\frac{1}{F \sigma \sqrt{T-t}}, \\
& N^{\prime}\left(d_{2}\right)=\frac{1}{\sqrt{2 \pi}} e^{-\left(d_{1}-\sigma \sqrt{T-t}\right)^{2} / 2}=\frac{1}{\sqrt{2 \pi}} e^{-d_{1}^{2} / 2} e^{\sigma \sqrt{T-t} d_{1}-\sigma^{2}(T-t) / 2}=N^{\prime}\left(d_{1}\right) e^{\ln \frac{F}{X}+\sigma^{2}(T-t) / 2-\sigma^{2}(T-t) / 2}= \\
& =N^{\prime}\left(d_{1}\right) \frac{F}{X} .
\end{aligned}
$$

Po dosadení a následných úpravách dostávame

$$
\frac{\partial c}{\partial F}=e^{-r(T-t)} N\left(d_{1}\right)
$$

Tento výsledok vyjadruje, že pri zmene ceny futures na spotovom trhu o jednu jednotku sa cena opcie zmení o hodnotu parametra $N\left(d_{1}\right)$ odúročenú o čas do splatnosti 
$(T-t)$ pričom táto hodnota sa pohybuje $\mathrm{v}$ otvorenom intervale $(0,1)$. Uvedený parameter sa nazýva delta kúpnej futures opcie. Výpočet parametra delta slúži aj na určenie toho, ako sa investor môže zabezpečit' proti možnej strate. Investor si vytvorí portfólio $\pi$, ktoré tvorí:

- mínus jeden derivát $f$ (tzn. predaj 1 futures opcie, call alebo put),

- plus delta futures kontraktov.

Toto portfólio je bezrizikové, ak platí delta $\pi=\frac{\partial \pi}{\partial F}=0$. Takéto portfólio sa nazýva delta - neutrálne portfólio, ktorého hodnota závisí iba od jedného aktíva $F$. Jeho výnos v krátkodobom časovom horizonte zodpovedá bezrizikovej úrokovej miere. Delta neutrálne portfólio je zložené $\mathrm{z}$ akcií a opcií $\mathrm{v}$ takom pomere, aby sa zisk, resp. strata $\mathrm{z}$ pozície v opciách vyrovnal stratou, resp. ziskom v pozícii v akciách.

Možným problémom $\mathrm{v}$ tomto portfóliu $\pi$ je, že parameter delta závisí od času a ak sa delta zmení, musí investor prehodnotit' portfólio, aby zostalo delta - neutrálne (prikúpit' alebo predat' čast' futures kontraktov). V praxi sa používajú dva typy delta hedgingu (zabezpečenia):

- dynamický delta hedging - portfólio sa pravidelne prehodnocuje, aby zostalo delta neutrálne, čo sa však nedá robit' spojite a vyžaduje to vysoké transakčné náklady;

- statický delta hedging - na začiatku je portfólio delta - neutrálne a d’alej sa neprehodnocuje, predpokladá sa, že hodnota parametra delta zostane konštantná. Tento predpoklad je samozrejme vel'mi zjednodušený.

\section{Priebeh parametra delta $\mathrm{z}$ hl'adiska času}

Nasledujúce obrázky ukazujú priebeh parametra delta call futures opcie pri zmene času do expirácie futures opcie. Zobrazený je parameter delta s meniacou sa cenou podkladového futures kontraktu 1 rok, 3 mesiace, 1 mesiac a 1 deň pred expiráciou. Cena futures kontraktu sa mení od $\$ 0$ do $\$ 50$ s krokom $\$ 0,5$.

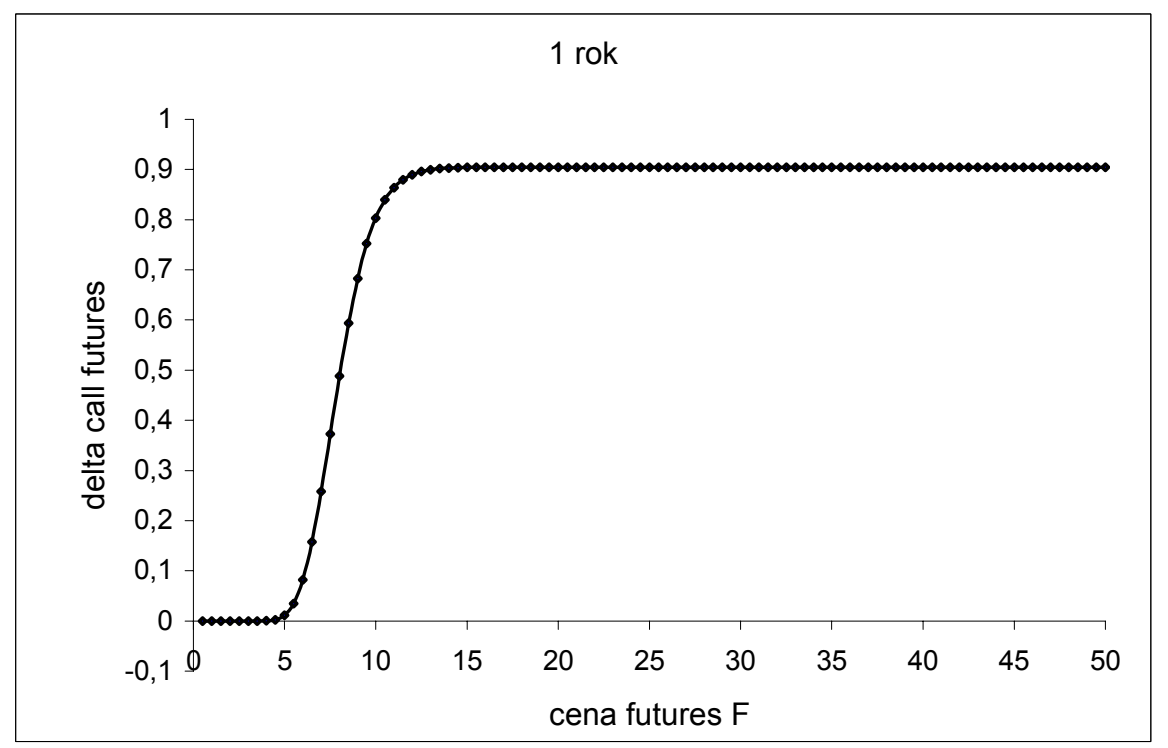

Obrázok 1 Delta call futures opcie 1 rok pred expiráciou 


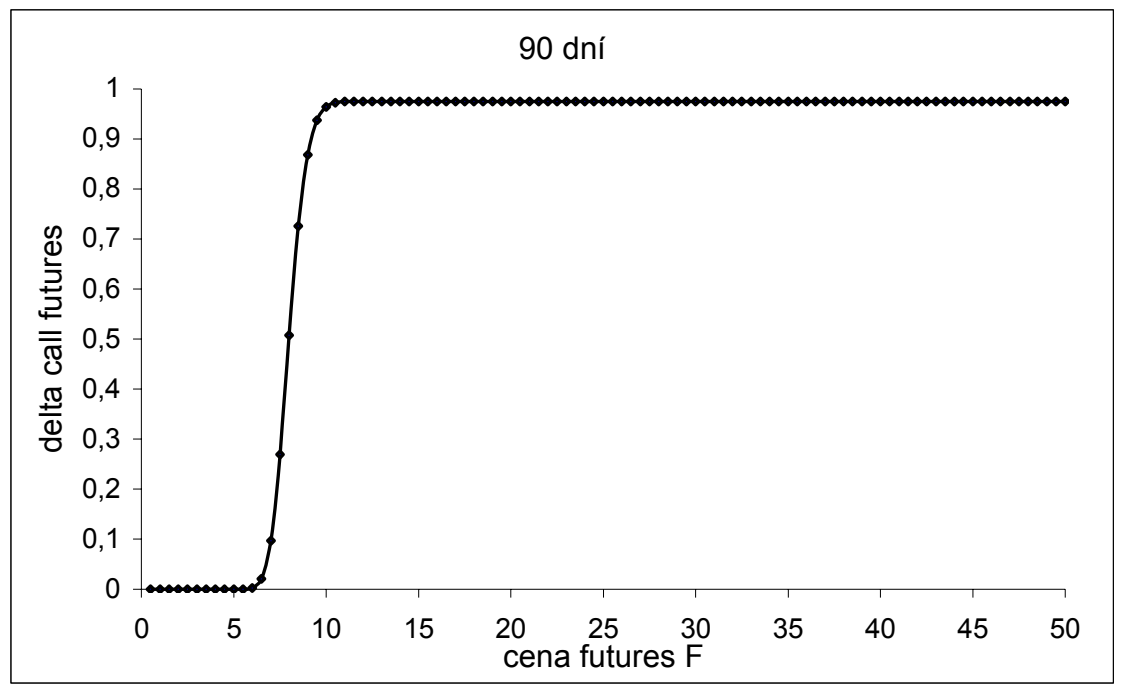

Obrázok 2 Delta call futures opcie 3 mesiace pred expiráciou

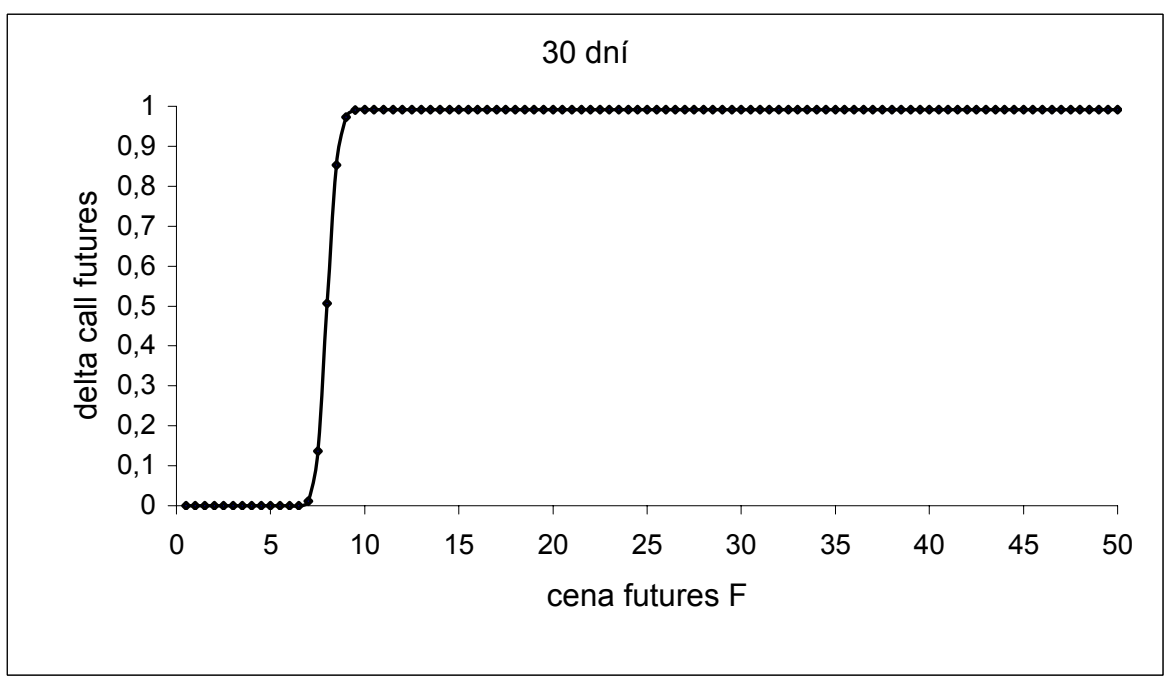

Obrázok 3 Delta call futures opcie 1 mesiac pred expiráciou

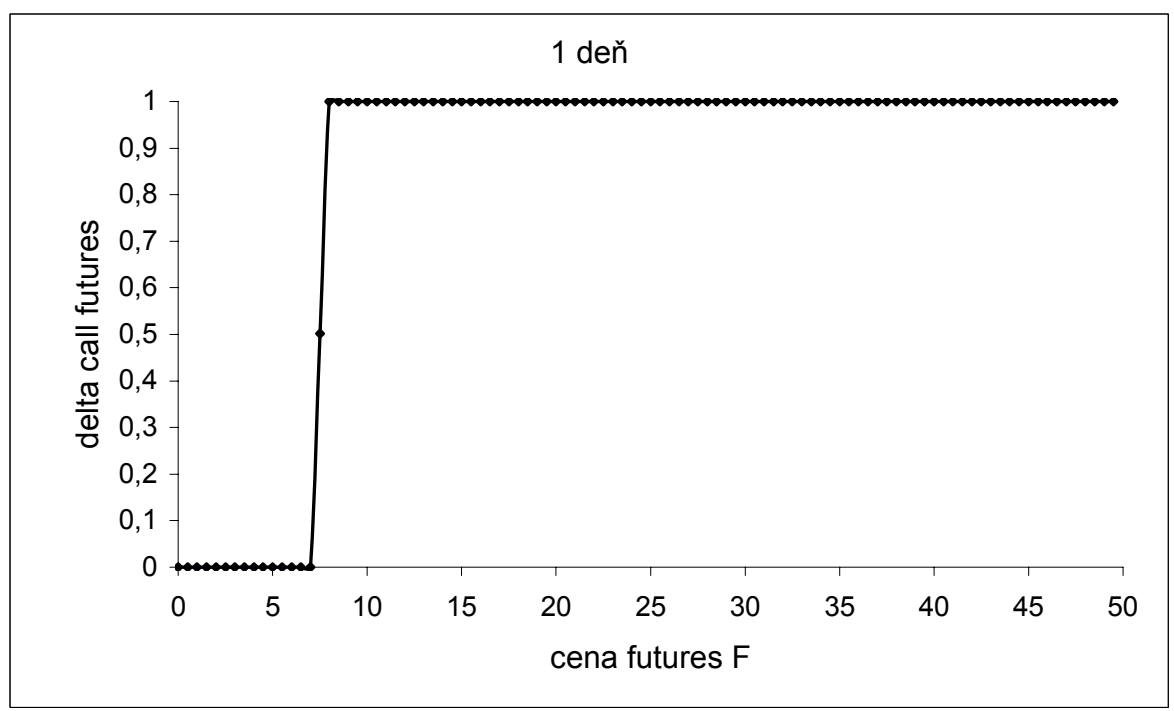

Obrázok 4 Delta call futures opcie 1 deň pred expiráciou 
Cena kúpnej futures opcie je na zmeny ceny podkladového futures kontraktu najcitlivejšia v oblasti ATM, teda ked' sa cena futures nachádza v blízkosti realizačnej ceny. $\mathrm{V}$ predchádzajúcich obrázkoch bola zvolená realizačná cena $\$ 8$. Z obrázkov vidno, že ked' sa cena futures kontraktu pohybuje okolo $\$ 8$, je delta futures call opcie najviac citlivá na zmenu času do expirácie. Napr. pre cenu futures $F=\$ 8$ pri čase 1 rok do expirácie je hodnota delta $=0,488$, pri čase 90 dní do expirácie je delta $=0,507$, rovnako aj pri čase 30 dní do expirácie delta $=0,507$ a pri čase do expirácie 1 deň je delta $=1$. To znamená, na udržanie rizikovo neutrálneho portfólia, že ak sa cena futures $\mathrm{F}$ zmení o $\$ 1$, cena zodpovedajúcej call futures opcie sa zmení o hodnotu delta, teda v čase 1 rok do expirácie sa zmení o $\$ 0,488$, ale $\mathrm{v}$ čase 1 deň do expirácie už o $\$ 1$.

V oblastiach OTM a ITM je cena opcie na zmenu ceny podkladového aktíva na spotovom trhu menej citlivá.

Ako sme už uviedli v predchádzajúcom texte, na priebeh parametra delta má vel'ký vplyv aj zmena času do expirácie kúpnej opcie. Preto je dôležité analyzovat' jeho priebeh z časového hl'adiska pri nezmenenej cene futures na cenu opcie v oblastiach OTM, ITM, ATM. So zmenou času sa parameter delta pred expiráciou blíži v oblasti OTM k hodnote 0 , v oblasti ITM k hodnote $e^{-r(T-t)}$, v oblasti ATM sa pohybuje okolo hodnoty $0,5 e^{-r(T-t)}$. Tieto tvrdenia vyplývajú z nasledujúcich úvah:

1. Ak sa cena call futures opcie nachádza v oblasti OTM, platí: $F e^{-r(T-t)}<X$, teda $\frac{F e^{-r(T-t)}}{X}<1$. Z toho vyplýva, že $\ln \frac{F e^{-r(T-t)}}{X} \rightarrow-\infty$, teda aj $d_{1,2} \rightarrow-\infty$. Potom $N\left(d_{1,2}\right) \rightarrow 0$. Ked'že delta call futures opcie $=\frac{\partial c}{\partial F}=\frac{\Delta c}{\Delta F}=N\left(d_{1}\right) e^{-r(T-t)}$, platí $\Delta c=N\left(d_{1}\right) e^{-r(T-t)} \cdot \Delta F \rightarrow 0$. Z toho vyplýva, že ak sa cena futures kontraktu zmení o jednotku, cena zodpovedajúcej call futures opcie sa zmení len vel'mi málo.

2. Ak sa cena call futures opcie nachádza v oblasti ITM, platí:

$F e^{-r(T-t)}>X$, teda $\frac{F e^{-r(T-t)}}{X}>1$. Z toho vyplýva, že $\ln \frac{F e^{-r(T-t)}}{X} \rightarrow \infty$, teda aj $d_{1}, d_{2} \rightarrow \infty$. Potom $\quad N\left(d_{1}\right), N\left(d_{2}\right) \rightarrow 1$. Pre delta call futures opcie potom platí $\Delta c=N\left(d_{1}\right) e^{-r(T-t)} \cdot \Delta F \rightarrow e^{-r(T-t)} \Delta F . \mathrm{Z}$ toho vyplýva, že ak sa cena futures kontraktu zmení o jednotku, cena zodpovedajúcej call futures opcie sa zmení jednotku odúročenú bezrizikovou úrokovou mierou $r$ o čas do splatnosti $(T-t)$.

3. Ak sa cena call futures opcie nachádza v oblasti ATM, platí:

$F e^{-r(T-t)}=X, \quad$ teda $\quad \frac{F e^{-r(T-t)}}{X}=1 . \quad \mathrm{Z}$ toho vyplýva, že $\quad \ln \frac{F e^{-r(T-t)}}{X}=0, \quad$ teda $d_{1,2} \rightarrow \frac{\left(r \pm \sigma^{2} / 2\right) \sqrt{T-t}}{\sigma}$ a ak $t \rightarrow T$, potom $\quad d_{1,2} \rightarrow 0^{+}$. Potom $N\left(d_{1,2}\right) \rightarrow 0,5 \quad$ a $\Delta c \rightarrow 0,5 e^{-r(T-t)} \Delta F$

$\mathrm{Z}$ toho vyplýva, že ak sa cena futures kontraktu zmení o jednotku, cena zodpovedajúcej call futures opcie sa zmení o $0,5 e^{-r(T-t)}$.

\section{Záver}

Priebeh parametra delta sa mení pri zmene času do expirácie call futures opcie, čo má význam pri jeho praktickom použití. Parameter delta sa využíva na delta - hedging, čo je zabezpečenie portfólia proti malým zmenám v cene podkladového aktíva počas malého časového intervalu v budúcnosti. Pozícia s nulovou deltou sa vzt’ahuje na delta neutrálne 
portfólio, ktorého výnos $\mathrm{v}$ krátkom čase $\mathrm{v}$ budúcnosti zodpovedá bezrizikovej úrokovej sadzbe. Je dôležité si uvedomit', že pozícia investora zostáva zabezpečená - delta neutrálna na relatívne krátky časový interval. To je spôsobené tým, že delta sa mení aj so zmenou v cene podkladového aktíva (futures kontraktu) aj s plynutím času. V praxi musí byt' zabezpečenie portfólia upravované periodicky.

Parameter delta spol'ahlivo určí zmenu ceny kúpnej opcie iba pri relatívne malých zmenách ceny futures na spotovom trhu. Pri väčších jednorázových zmenách ceny futures na spotovom trhu, predovšetným v oblasti ATM dochádza použitím tohto parametra k tým väčšej chybe, čím väčšia je zmena ceny futures na spotovom trhu. V takom prípade je potrebné použit' druhú deriváciu funkcie ceny kúpnej futures opcie podl’a $F$ - parameter gamma.

\section{Literatúra}

[1] Hull, J. C.: Options, Futures, and Other Derivatives. 3. vyd. New York: PrentiCe Hall, 1997. 572 s. ISBN 0131864793

[2] ŠEVČOVIČ, D.: Analytické a numerické metódy oceňovania finančných derivátov. Dostupné na: <http://www.iam.fmph.uniba.sk/institute/sevcovic/skripta/derivaty/index. html>

[3] JÄCKEL, P.: Monte Carlo Methods in Finance. 1. vyd. Chichester, West Sussex, England: J. WILEY AND SONS, 2002. 222 s. ISBN 0-471-49741-X

[4] Chovancová, B. - JankovskÁ, A. - HÁjnikovÁ, J. - Majcher, M. - Šturc, B.: Finančný trh: nástroje, transakcie, inštitúcie. 1. vyd. Bratislava: EUROUNION, 1999. 538 s. ISBN 8088984033 